\title{
Breeding sheep with 4 teats in a flock in Devon, England
}

\author{
D. A. R. DAVIES
}

Department of Animal Husbandry, University of Liverpool, Leahurst, Neston, South Wirral, L64 7TE, England

\begin{abstract}
A survey of British breeds and crossbreeds revealed that they contained ewes with extra teats, in many cases even functional. In one flock, a crossbred mix of three breeds, some selection for 4 teats had taken place and 79 of 147 ewes had 4 teats and 2 ewes had 6 teats. Length of the extra teats varied up to a 09:1 ratio relative to the rear. 38 of the 79 ewes had a ratio between $0.6: 1$ and $0.9: 1$. The distance from front to rear was generally between 0.2 and 0.5 of that from side to side. In 1986 the 147 ewes were divided into 5 unequal size family groups, A (51), B (53), C (21), D (6), each group mated to one ram with 4 teats, and group E (12) to a ram with 2 teats but whose dam had 4 . The mean teat number for the ewes in the groups was $3.26,2.95,2.70,4.00$ and 3.76 resp., and for their offspring $3.84(91), 3.06$ (95), 3.4 (37), 3.3 (12) and 3.1 (9). More detailed analysis of the larger groups, A, B and C, showed that the proportion of lambs with 4 teats from 4 teated ewes was $0.96,0.76$ and 0.88 , resp., and that in groups A and B the proportion of lambs with 4 teats from 2 teated ewes was 0.78 and 0.31 respectively. Milk production of 14 ewes with well developed fore teats was measured in the first 10 days of lactation using the oxytocin technique. The mean yield of the front teats was only $0.057 \pm 0.010$ of the rear, indicating the wide variation and the limited production of the population at present in the flock.
\end{abstract}

Index words: functional extra teats, teat length, teat distance, teat number, milk production

\section{Introduction}

The presence of extra teats may result in higher yields, but in Britain the main interest is in having ewes with four functional teats so that triplet lambs can suck on the ewe simultaneously and thereby reduce the problems of uneven growth and teat damage.

\section{Materials and methods}

Ewes of many breeds and crosses have been found with extra teats and a Devon farmer, Philip CAUnter, has carried out considerable selection for the trait within his flock, a crossbred mix of Dorset Horn, Border Leicester and Lleyn with a prolificacy of 1.7. 
In 1986 the flock comprised 147 ewes, 79 of which had 4 teats and 2 had 6 teats. These were divided into five unequal size groups $\mathrm{A}$, B, C, D and E, as an initial step in setting up a closed flock breeding scheme. Groups A, B, $\mathrm{C}$ and D were each mated to a single 4 teat ram and group E to a ram with 2 teats but whose dam had 4 teats.

The number of teats of ewes and their progeny was recorded and also in ewes the length of and the distance between teats was measured. A small number of ewes with well developed fore teats was milked following an oxytocin injection.

\section{Results}

The teat number of ewes and lambs in the groups in the 1987 lambing season shown in Table 1 indicates that there were noticeably different results in the five progeny groups. Nevertheless it should be relatively easy with selection to increase the mean number of teats in a flock and to maintain a predominately 4 teated flock.

Table 2 shows a more detailed analysis of the two largest groups A and B. The significant differences between $\mathrm{A}$ and $\mathrm{B}$ lamb groups ( $\chi^{2}$ for 4 and 2 teat ewe matings $=6.4$ and 33.1 respectively) suggest teat number was under the control of two or more genes.

The distance from front to rear teats was generally between 0.2 and 0.5 of that from side to side. The ratio of the length of the extra teats relative to the rear varied up to $0.9: 1$. 38 of the ewes had a ratio of $0.6: 1$ or more.

Milk yields were estimated in 16 ewes within the latter group (Table 3). The proportion of yield varied considerably and the correlation between front : rear length and propor-
Table 1. Mean teat number of ewes and lambs. 1987 lambing season.

\begin{tabular}{lrrrrr}
\hline Family Group & A & B & C & D & E* $^{*}$ \\
\hline $\begin{array}{l}\text { Ewes (E) } \\
\text { Lambs (L) }\end{array}$ & 3.3 & 3.0 & 2.7 & 4.0 & 3.7 \\
$\begin{array}{l}\text { Difference } \\
\text { change (L) v (E) }\end{array}$ & +0.5 & 3.1 & 3.4 & 3.3 & 3.1 \\
\hline
\end{tabular}

* Ram used had 2 teats; in all other groups rams had 4 teats.

Table 2. Proportion of lambs with 4 and 2 teats from 4 or 2 teated ewes in family groups A and B (one 4 teated ram used per group).

\begin{tabular}{lcccccc}
\hline Group & \multicolumn{2}{c}{$\mathrm{A}(\mathrm{n}=52)$} & & \multicolumn{2}{c}{$\mathrm{B}(\mathrm{n}=51)$} \\
\cline { 2 - 3 } \cline { 7 - 8 } Ewe teat number & & 4 & 2 & & 4 & 2 \\
\hline Lamb teat & 4 & 0.96 & 0.88 & & 0.76 & 0.24 \\
number & 2 & 0.04 & 0.12 & & 0.24 & 0.76 \\
\hline
\end{tabular}

Table 3. Proportion of total milk from front teats of ewes in which they were well developed $(\mathrm{n}=16)$.

\begin{tabular}{lccc}
\hline & $\bar{x}$ & range & s.e. \\
\hline $\begin{array}{l}\text { Front : rear length } \\
\text { Proportion of yield }\end{array}$ & 0.74 & $0.6 \rightarrow 0.9$ & 0.025 \\
from front teats & 0.057 & $0.001 \rightarrow 0.12$ & 0.0098 \\
\hline
\end{tabular}

Correlation $(r)$ between front : rear length and proportion of yield from front teats $\quad=0.16$

tion of yield from front teats was low $(r=0.16)$. It would appear that length of teat may not be a very precise guide to potential milk yield. There is, therefore, a need to record yield in early lactation if the best producers are to be identified and then used for further breeding. This has, therefore, become a high priority in the flock's further development. 